\title{
Macroeconomic trade-offs and external vulnerabilities of human development in Nicaragua
}

\author{
Marco V. Sánchez Cantillo
}

ABSTRACT

Nicaragua is making progress towards the Millennium Development Goals, but is set to miss a number of targets in 2015. This paper's general equilibrium analysis shows that it is unfeasible for the government to step up spending in order to meet these targets by the 2015 deadline. Any boost to public spending and financing would have to be front-loaded, which would entail pernicious macroeconomic trade-offs. A more realistic scenario would be to postpone meeting the goals until 2020. In that case, the allocation of public spending would spur economic growth without causing macroeconomic hardships, although the country would nevertheless remain highly vulnerable to external shocks.

KEYWORDS

JEL CLASSIFICATION

AUTHOR
Economic conditions, macroeconomics, human development, economic development, millennium development goals, development indicators, Nicaragua

$\mathrm{C} 68, \mathrm{O} 2, \mathrm{O} 11, \mathrm{O} 54$

Marco V. Sánchez Castillo is a Senior Economic Affairs Officer, Development Policy and Analysis Division, Department of Economic and Social Affairs, United Nations. sanchez-cantillo@un.org 


\section{I}

\section{Introduction}

Despite the structural changes that its economy has undergone in the past two decades, Nicaragua lags behind most Latin American and Caribbean countries in terms of economic and human development. This is largely attributable to the long-lasting effects of armed conflict in the 1980s and the resulting decision of the United States and international financial institutions to break off economic and financial relations with the country (Sánchez and Vos, 2006). The country's foreign debt position was unsustainable in the late 1980s, with this debt representing $940 \%$ of gross domestic product (GDP) in 1989. Both the peace process and the resumption of economic and financial relations with the United States and international financial institutions allowed Nicaragua to shift course in the early 1990s.

Massive inflows of foreign grant aid paved the way for the government to implement an economic stabilization programme involving restrictive monetary policies and rigorous fiscal discipline. The first signs of economic stability were followed by fiscal and State reforms; the gradual liberalization of trade, foreign-exchange and financial regimes; and the phasing-out of controls on foreign direct investment (FDI). During the 1990s, the public finances were healthier and better controlled, inflation was curbed and international trade picked up speed. Although it was still very high, foreign debt had shrunk to $175 \%$ of GDP by 1999 .

In the late 1990s and early 2000s, the Government of Nicaragua, with assistance from international financial

This paper is one of the outputs of the project "Strengthening Macroeconomic and Social Policy Coherence through Integrated Macro-Micro Modelling", which was implemented by the United Nations Department of Economic and Social Affairs, in collaboration with the country office of the United Nations Development Programme (UNDP) in Nicaragua and the Ministry of Finance and Public Credit of Nicaragua. The author is grateful to all those who participated in the project and the institutions with which they are affiliated, especially to Manuel A. Deshon for his inputs into the initial drafts and Janet Ramírez and Martín Cicowiez for their prominent role in compiling and using datasets to assist in the calibration of the modelling tools used. The author also thanks all those who provided comments on a previous version of the paper presented at the Annual Conference of the Human Development and Capability Association (HDCA) held in Managua on 9-13 September 2013. Martín Cicowiez and Marcelo Lafleur also provided valuable comments to improve the paper. The views expressed are those of the author and do not necessarily reflect those of the United Nations or the implementing partners of the Department of Economic and Social Affairs capacity development project. institutions, introduced a number of programmes and strategies to reduce the country's stubbornly high levels of poverty. In 2000, the country endorsed the United Nations Millennium Declaration and pledged to pursue the Millennium Development Goals. The Government adopted a number of targets associated with human development indicators and extreme poverty reduction to be met by 2015, and incorporated those targets into the country's poverty reduction strategies -including the Heavily Indebted Poor Countries (HIPC) Initiative- and development plans. Some headway has been made on social indicators and poverty reduction, but significant gaps remain, thus derailing the country's progress towards a number of the Millennium Development Goals. Some targets, such as the national target on extreme poverty reduction, have already been met, but others remain pending. For example, a large number of boys and girls still do not complete primary school, coverage of basic sanitation services is worryingly low and maternal mortality remains a challenge. Policymakers will have to step up their efforts to achieve the Millennium Development Goals and put the country on a solid footing towards furthering human development. The level and effectiveness of public spending and financing will need to be raised, but in practice achieving this will also depend on the speed and sustainability of economic growth.

Structural changes in the 1990s did not translate into a fast and sustained economic recovery. Economic growth slowed in the second half of the 2000s owing to internal and external factors. Remittances from abroad - a fundamental source of income for a large portion of the poor population - and FDI flows showed unexpected downturns, and the terms of trade deteriorated as a result of oil and food price hikes and reductions in the world prices of key export commodities (Gámez and others, 2011; Sánchez, 2011). Slow economic growth and external vulnerabilities were exacerbated by the global financial crisis in 2008-2009 when international trade, FDI and remittances once again contracted, thus exerting pressure on the balance of payments and pushing per capita GDP growth down to $-2.5 \%$ in 2009 . This crisis also manifested itself through setbacks in a number of human development indicators, making the achievement of the Millennium Development Goals more challenging and costly for Nicaragua (Sánchez and Vos, 2009). 
The economy recovered from the global financial crisis to grow by about 5.0\% on average in 2011-2012. While foreign debt has been decreasing steadily, it is also true that social programmes continue to rely on foreign resources for their funding. In view of international donors' diminishing allocation of aid to developing countries, human development aspirations in Nicaragua will depend on access to foreign credit under favourable terms. Against this backdrop, this paper addresses three questions.

- Can the government step up public spending in order to achieve the Millennium Development Goals by 2015 without causing macroeconomic hardships?

- Can the government rely on higher and more sustained economic growth to mobilize resources for financing public spending requirements?

- If not, what would be a more realistic scenario for securing that financing and what external vulnerabilities could prevent the country from achieving the Goals?

This paper updates the estimates published by Sánchez and Vos (2009 and 2010) on the additional public spending that would be required to meet the Millennium Development Goals by 2015 in Nicaragua. The period of analysis is extended beyond 2015 in order to assess feasible scenarios for furthering human development (within the Millennium Development Goal framework) without causing marcroeconomic hardships. In addition, the vulnerability of these feasible scenarios to external shocks, given the small size and open nature of Nicaragua's economy, is also evaluated. In this regard, the paper draws conclusions that could inform the setting of the post-2015 sustainable development agenda. That process, led by the United Nations, to help define the future global development framework will seek to address the gaps associated with the Millennium Development Goals and complement the development agenda with new sustainability goals. The analysis involves the application of a computable general equilibrium (CGE) model calibrated with Nicaraguan data to generate a series of scenarios that can be evaluated. The results from the CGE model are in turn used to apply a microsimulation model that allows income poverty and inequality indicators to be estimated for these scenarios. Rather than focusing on describing these models in detail, the emphasis of the paper is on interpreting the results of the scenarios in order to draw conclusions that can be used to make policy recommendations.

Following this introduction, section II highlights salient aspects of past progress made towards a number of the Millennium Development Goals and the outlook for the future, outlines the main challenges confronted by Nicaragua with respect to meeting these development goals, and underscores the need for sustained economic growth in the face of external shocks. The modelling framework is described in section III. The data sources used for the economy-wide and microsimulation models and for the baseline scenario are described in section IV, followed in section $\mathrm{V}$ by the analysis of the findings from the baseline scenario and several alternative scenarios. Key conclusions and policy recommendations are summarized in section VI.

\section{II}

\section{Millennium Development Goal achievements and pending tasks}

\section{Progress, gaps and challenges}

Nicaragua's poverty reduction strategy emphasizes the attainment of the Millennium Development Goals. Since the mid-2000s, resources freed up by debt relief and additional donor contributions granted through the HIPC Initiative have been allocated to the poverty reduction strategy. Under the strategy, the government has stepped up social spending, although not to the extent required to put the country fully on-track towards meeting the Goals, as will be shown below. Public social spending rose slightly from $9.1 \%$ of GDP to $9.6 \%$ of GDP between 2002 and 2012 (see table 1), but it remains well below the regional weighted average of $18.6 \%$ of GDP estimated by the Economic Commission for Latin America and the Caribbean (ECLAC, 2013). ${ }^{1}$ The sectoral allocation of this spending as a percentage of GDP is also fairly stable.

\footnotetext{
${ }^{1}$ Public social spending in Nicaragua would have represented just over $12 \%$ of GDP had it not been for a change in the base year for calculating GDP, which corrected a $30 \%$ underestimation in the level of output.
} 
Measured in per capita terms, rather than as a share of GDP, public social spending grew from US\$ 69.5 in 2002 to US\$ 166.6 in 2012; yet it remains low by regional standards. Efforts to step up public social spending have not been bold enough in Nicaragua: the country still faces profound human development deficits despite having absorbed considerable sums of foreign grand aid. Part of the problem is that only a fraction of the debt relief is earmarked for poverty reduction programmes. In 2005, for example, only $53 \%$ of those funds were earmarked for poverty reduction and the remaining $47 \%$ were allocated to the repayment of domestic central government debt (Guimarães and Avendaño, 2011). The government has stepped up efforts to finance public social spending and has even used fiscal revenues to safeguard such spending at times of crisis. Nonetheless, these efforts are not reflected in higher public social spending as a proportion of GDP because foreign financing of this spending has been declining (see table 1).

The programmes and strategies targeting poverty reduction and human development goals have enabled progress towards the Millennium Development Goals, but has not brought all of them within reach by 2015 (see table 2). Poverty at the national level has decreased for several reasons, in particular, improved living conditions in rural areas. That improvement is attributable in part to the effectiveness of programmes promoting the production of food staples, lower consumer prices for these products and, in more general terms, inflows of remittances. The national extreme poverty target (16.3\%) has already been met; however, the international target $(9.7 \%)$ of halving the level of extreme poverty relative to its 1993 level remains a daunting aspiration. The volatility of economic growth has impeded further reductions in extreme poverty. Measured as the percentage of the population living on less than US\$ 1 a day, extreme poverty rose somewhat between 1998 and 2001 as the economy slowed. During these years, a fraction of public social spending was reallocated to natural disaster recovery measures. The population living in moderate and extreme poverty expanded again in 2005 during another economic downturn. Poverty reduction programmes helped to revert this situation: moderate and extreme poverty had fallen by 2009 , however, the most recent survey data available during the drafting of this paper do not reflect the full impact of the global financial crisis on poverty.

Outcomes in primary education have by and large been satisfactory. Net enrolment has increased, but must rise by a further 11 percentage points in order for the country to meet one of the key targets of Goal 2. Nonetheless, the major challenge in education is not net enrolment, but the fact that less than $50 \%$ of the students who enrol in primary school succeed in completing the cycle. Through public spending on education, infrastructure in the sector has been improved and assistance has been provided to poor students through school lunch programmes and conditional cash transfers. Teaching quality has also been addressed by modernizing the education sector. In spite of these efforts, spending to date has been either insufficient or ineffective, or both, because repetition and dropout rates remain high. The public sector faces enormous limitations on infrastructure capacity in terms of schools and teaching materials.

Nicaragua: public spending earmarked for the poverty reduction strategy, 2002-2012

\begin{tabular}{|c|c|c|c|c|c|c|c|c|c|c|c|}
\hline & 2002 & 2003 & 2004 & 2005 & 2006 & 2007 & 2008 & 2009 & 2010 & 2011 & 2012 \\
\hline Public social spending (percentages of GDP) & 9.1 & 11.1 & 12.0 & 13.1 & 9.6 & 10.2 & 10.3 & 9.9 & 9.9 & 9.6 & 9.6 \\
\hline Education & 2.6 & 2.9 & 2.8 & 3.1 & 2.4 & 2.6 & 2.8 & 2.9 & 2.7 & 2.5 & 2.4 \\
\hline Health & 2.9 & 3.2 & 2.9 & 3.2 & 2.5 & 2.8 & 2.7 & 2.7 & 2.8 & 2.6 & 2.7 \\
\hline Water and sanitation & 0.1 & 0.0 & 0.1 & 0.0 & 0.1 & 0.0 & 0.1 & 0.1 & 0.1 & 0.1 & 0.1 \\
\hline Other & 3.5 & 4.9 & 6.2 & 6.7 & 4.6 & 4.8 & 4.7 & 4.1 & 4.4 & 4.3 & 4.4 \\
\hline Per capita public social spending (dollars) & 69.5 & 85.4 & 99.2 & 116.9 & 117.9 & 135.7 & 150.0 & 140.7 & 145.8 & 156.6 & 166.6 \\
\hline \multicolumn{12}{|l|}{ Financing of public spending (percentages) } \\
\hline Fiscal resources & 54.8 & 33.2 & 28.3 & 38.7 & 52.0 & 51.7 & 49.6 & 55.2 & 57.3 & 61.9 & 65.6 \\
\hline External development cooperation & 36.5 & 45.5 & 48.4 & 42.3 & 33.3 & 32.3 & 33.5 & 28.3 & 27.3 & 22.6 & 21.2 \\
\hline External debt relief & 8.7 & 21.3 & 23.3 & 19.0 & 14.6 & 15.9 & 16.9 & 16.5 & 15.5 & 15.5 & 13.3 \\
\hline
\end{tabular}

Source: budget reports from the Ministry of Finance and Public Credit.

Note: some figures from the budget reports were converted into local currency using the average exchange rate of the Central Bank of Nicaragua. The reduction in public social spending as a percentage of GDP from 2005 to 2006 is explained by a change in the base year for calculating GDP from 1994 to 2006, which corrected a 30\% underestimation in the level of GDP. Fiscal resources include tax revenues and earmarked revenues. External development cooperation includes grants and loans. External debt relief includes debt relief under the Heavily Indebted Poor Countries Initiative and cancellation of Paris Club debt. GDP: gross domestic product. 
TABLE 2

Nicaragua: Millennium Development Goal and poverty indicators, 1990-2011 and target for 2015

\begin{tabular}{|c|c|c|c|c|c|}
\hline Indicator & 1990 & 2000 & 2005 & 2011 & Target for 2015 \\
\hline National moderate poverty (percentages) & $\begin{array}{c}50.3 \\
(1991)\end{array}$ & $\begin{array}{c}45.8 \\
(2001)\end{array}$ & 48.3 & $\begin{array}{c}42.5 \\
(2009)\end{array}$ & \\
\hline Goal 1: national extreme poverty (percentages) & $\begin{array}{c}19.4 \\
(1991)\end{array}$ & $\begin{array}{c}15.1 \\
(2001)\end{array}$ & 17.2 & $\begin{array}{c}14.6 \\
(2009)\end{array}$ & 9.7 \\
\hline Goal 2: net enrolment rate in primary education (percentages) & $\begin{array}{c}72.6 \\
(1991)\end{array}$ & 80.5 & 87.1 & 88.9 & 100.0 \\
\hline Goal 2: students who begin and complete primary education (percentages) & $\cdots$ & 35.4 & $\begin{array}{c}43.0 \\
(2006)\end{array}$ & $\begin{array}{c}41.5 \\
(2010)\end{array}$ & \\
\hline Goal 4: under-five child mortality (deaths per 1000 live births) & 72.0 & $\begin{array}{c}37.0 \\
(2001)\end{array}$ & $\begin{array}{c}35.0 \\
(2006)\end{array}$ & 25.0 & 17.0 \\
\hline Goal 5: maternal mortality (deaths per 100000 live births) & 160.0 & 87.0 & 86.5 & 62.0 & 40.0 \\
\hline Goal 7: population with access to an improved water supply (percentages) & 57.7 & $\begin{array}{c}78.6 \\
(2002)\end{array}$ & 90.5 & $\ldots$ & 85.0 \\
\hline Goal 7: population with access to improved sanitation (percentages) & $\ldots$ & $\begin{array}{c}27.9 \\
(2002)\end{array}$ & 37.2 & $\begin{array}{c}39.8 \\
(2008)\end{array}$ & 72.5 \\
\hline
\end{tabular}

Source: National Institute of Information for Development (INIDE) for poverty data; Ministry of Education (MINED) for education data; Ministry of Health (MINSA) and Pan American Health Organization (PAHO) for mortality data except for 2011; National Human Development Plan 2012-2016 for mortality data for 2011; and Nicaraguan Water and Sewerage Enterprise (ENACAL) for data on water and sanitation.

Note: poverty rates represent the percentage of the population whose per capita consumption falls below the respective official poverty lines.

There are not enough qualified teachers and their pay is low. Only recently were all primary schools in rural areas instructed to deliver education for all grades of the cycle. Poor well-being conditions, migration and the cost of education critically limit the demand for education such that a large number of boys and girls drop out of school or never enrol, especially in the rural areas where poverty is higher and child labour remains a worrisome reality.

Under-five mortality has decreased systematically as social policy has promoted better and more comprehensive care provision in order to reduce children's nutritional and educational vulnerability. This trend has been strengthened by the extension of vaccination and breastfeeding campaigns to larger swathes of the population, the wider use of oral rehydration and infection control therapies, new public investment in basic services in rural areas, and integrated social protection systems targeting extremely poor children under the age of 6 years. Yet meeting the target of 17 deaths per 1,000 live births remains a challenge and will require a larger share of public spending on health being earmarked to further reduce the prevalence of diarrhoeal diseases, acute respiratory infections, premature births and the problems associated with low birth weight, asphyxia and sepsis.

The outlook is less encouraging for maternal mortality, even though the number of deaths per 100,000 live births fell from 160 in 1990 to 62 in $2011 .^{2}$ Complications during childbirth continue to be one of the main causes of death for women of reproductive age. Achieving the target of reducing maternal mortality to 40 deaths per 100,000 live births by 2015 will require higher and more sustained growth in public health spending. The priority areas are to improve the quality and coverage of prenatal and postnatal care, assistance during childbirth and the prevention of complications in pregnancy. Improvements must be made in terms of health service efficiency, increasing the coverage and capacity of health infrastructure, especially at the primary and secondary levels of care, and expanding preventive care and health promotion for households and communities, especially in rural areas.

Last, but not least, Nicaragua also committed to halving the proportion of the population without access to drinking water and improved sanitation services between 1990 and 2015. The target for drinking water has already been met, owing mostly to investment programmes by the Nicaraguan Water and Sewerage Enterprise (ENACAL), which have expanded the coverage of drinking water supplies in rural areas and in neighbourhoods in Managua.

\footnotetext{
${ }^{2}$ Maternal mortality figures for Nicaragua vary significantly depending on the source.
} 
The sewerage programmes of ENACAL and the rural latrine projects of the Emergency Social Investment Fund have benefited thousands of households in recent years. Nonetheless, only $40 \%$ of the population had access to improved sanitation services in 2011. The country will struggle to meet its target of increasing coverage to $72.5 \%$ of the population by 2015 , unless there is a more sustained increase in public spending to expand and improve the sewerage and rural latrines infrastructure.

Only by stepping up public social spending to implement cost-effective policies will the gaps in primary education, maternal mortality and basic sanitation be eliminated. Sánchez and Vos (2009 and 2010) found that continued economic growth and the implementation of the public spending policies in place before the global financial crisis would contribute to notable progress on a number of indicators, but not enough to meet all targets by 2015 . These authors estimate that, before the global financial crisis, the additional public social spending required to meet these targets in Nicaragua ranged from $3.6 \%$ of GDP to $4.7 \%$ of GDP per year for the period 2000-2015, depending on the source of financing. These estimates were revised upward by 1.7 percentage points of GDP after taking into consideration the effects of the global financial crisis on private social spending and the Millennium Development Goals. ${ }^{3}$

\section{Economic growth and external vulnerability}

Sustained economic growth is badly needed in Nicaragua to close the development gaps described above. An emphasis should be placed on increasing incomes and boosting private demand for social services, which would enable the government to raise tax revenues and thus increase public social spending and investments in infrastructure. As indicated above, the Government of Nicaragua has stepped up efforts to finance public social spending and has even used fiscal revenues to safeguard that spending during crisis periods. This is particularly important at a time when access to concessional loans and grant aid has been declining; in fact, grant aid represented a mere $2.6 \%$ of GDP per year in the period 2010-2012 (see table 3).

Tax revenues have risen steadily on the back of a number of tax reforms since the mid-1990s: they

\footnotetext{
3 An update of these estimates is presented below, but the scenario analysis is refined in two respects. First, in view of the short time span to 2015, the simulation period was extended to assess feasible financing strategies for the spending required to achieve the Millennium Development Goals. Second, the analysis sheds light on the vulnerability to external shocks of a feasible scenario of MDG achievement.
}

represented $20.8 \%$ of GDP per year in the period 2010-2012, 8 percentage points higher than in the second half of the 1990s (see table 3 ). The most recent tax reform was the Tax Coordination Act (Act No. 822), passed in 2012. However, new reforms to expand the tax base and boost revenues are not expected to raise revenues substantially. It is precisely the success of past fiscal reforms that has narrowed the scope for generating even higher tax revenues in a relatively short period of time. Public spending policies will continue to rely heavily on foreign resources, although there is also a remote possibility that shallow domestic financial markets will be able to mobilize some domestic resources.

Fragile access to concessional loans and aid, debt sustainability concerns and a lack of scope for further raising tax revenues in the short term undermine the country's ability to mobilize resources in support of human development goals. Sustained economic growth is thus critical to creating more space for domestic resource mobilization in support of human development. Alas, the economic achievements resulting from stabilization efforts and economic reforms, as well as some episodes of favourable external conditions, have not translated into the fast and sustained economic recovery that Nicaragua needs in the long run (see figure 1). Per capita GDP growth was unstable in the $1990 \mathrm{~s}$, when it averaged $2.7 \%$ per year, and it subsequently declined to $2.2 \%$ per year in 2000-2004 (see table 3). The prospects subsequently improved, though, as per capita GDP grew by $5.8 \%$ in 2005-2009 and by 6.8\% in 2010-2012.

Various studies show that the stability of economic growth in Nicaragua has been adversely affected by unfavourable external conditions (see, for instance, Gámez and others, 2011; Sánchez, 2011; Sánchez and Vos, 2006). External vulnerabilities are rooted in a number of factors. For example, export promotion policies and mini-devaluations of the exchange rate have enhanced export competitiveness, but a lack of export diversification remains a major concern, especially because exports are among the main drivers of economic growth in Nicaragua. Textiles (including leather products), meat and coffee represented, respectively, $16 \%, 17 \%$ and $9 \%$ of total exports in 2011. Together, these three product groups accounted for nearly half of total exports. Fortunately for Nicaragua, the value of its key exports has not been undermined seriously by world prices, which on the whole remained favourable between 1994 and 2011. Yearly export prices show only one fall in textile prices (8\% in 2009) and four reductions in coffee prices (each by about $20 \%$ in 1996, 1999, 2000 and 2001) (see figure 2). Coffee prices fell by $23 \%$ in 2013 (data not 
TABLE 3

Nicaragua: macroeconomic indicators, 1990-2012

(Annual averages)

\begin{tabular}{|c|c|c|c|c|c|}
\hline Indicator & $1990-1994$ & 1995-1999 & $2000-2004$ & 2005-2009 & 2010-2012 \\
\hline \multicolumn{6}{|c|}{$\begin{array}{l}\text { Public finances, official development assistance and foreign } \\
\text { public debt (percentages of } G D P \text { ) }\end{array}$} \\
\hline Tax revenue & 20.5 & 12.9 & 15.3 & 18.7 & 20.8 \\
\hline Fiscal balance, before grants & -10.2 & -5.7 & -6.9 & -3.3 & -1.8 \\
\hline Fiscal balance, after grants & -3.7 & -1.4 & -3.3 & -0.3 & -0.2 \\
\hline Foreign borrowing & 7.6 & 3.9 & 4.3 & 2.8 & 2.1 \\
\hline Domestic borrowing & -4.0 & -2.5 & -2.2 & -2.6 & -1.9 \\
\hline Official development assistance & 41.4 & 17.1 & 13.7 & 9.0 & 5.4 \\
\hline Concessional loans & 18.9 & 8.9 & 6.5 & 4.0 & 2.8 \\
\hline Grants & 22.6 & 8.2 & 7.2 & 5.0 & 2.6 \\
\hline Foreign public debt & 593.9 & 206.6 & 152.8 & 61.9 & 42.7 \\
\hline \multicolumn{6}{|c|}{ External sector (percentages of GDP) } \\
\hline Current account balance & -46.2 & -23.4 & -18.7 & -14.5 & -12.0 \\
\hline Foreign direct investment & 1.7 & 4.8 & 5.2 & 5.4 & 7.9 \\
\hline Remittances & 1.1 & 4.7 & 9.6 & 10.4 & 9.6 \\
\hline \multicolumn{6}{|l|}{ Production (growth rate) } \\
\hline Real GDP & 0.6 & 5.4 & 3.1 & 3.1 & 4.8 \\
\hline Real GDP per capita & 13.3 & 2.7 & 2.2 & 5.8 & 6.8 \\
\hline
\end{tabular}

Source: Central Bank of Nicaragua.

Note: the fiscal balance and its financing refers to the non-financial public sector. The net concession of loans was considered part of the fiscal balance until 2000, after which it became part of domestic borrowing. Grants include some liquid foreign grants linked to projects and interim debt relief from the Heavily Indebted Poor Countries Initiative.

GDP: gross domestic product.

FIGURE 1

Nicaragua: GDP and per capita GDP growth in real terms, 1991-2012

(Percentages)

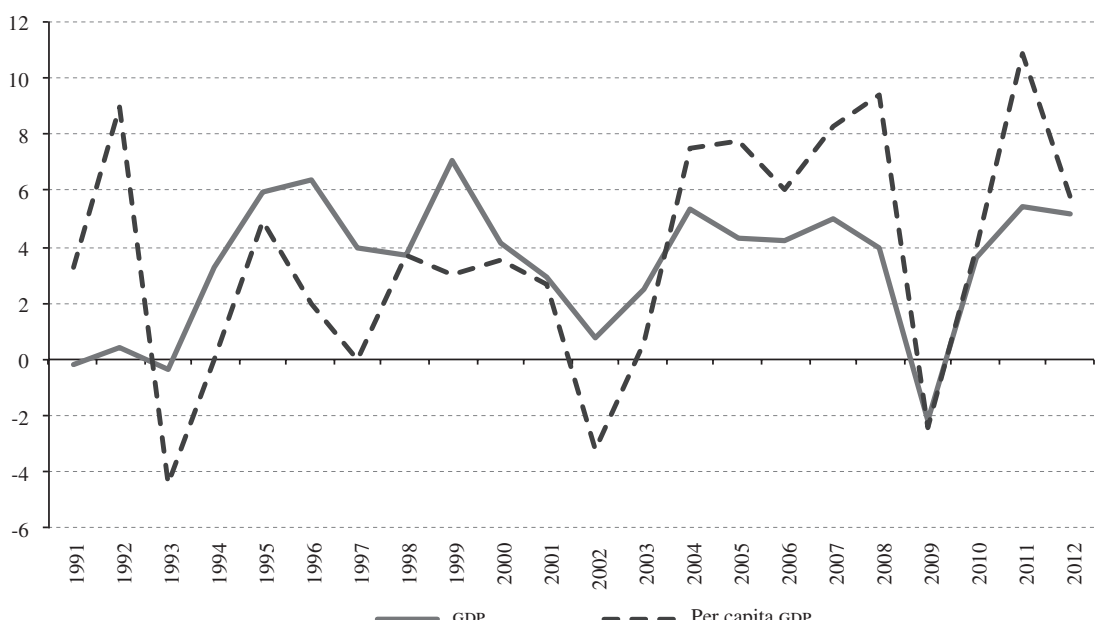

Source: Central Bank of Nicaragua.

GDP: gross domestic product.

shown in the figure). World prices remain a potential source of external vulnerability in view of the lack of export diversification.

The value of total imports has grown faster than the value of total exports, largely because of the rising refined oil import bill. Refined oil represented $11 \%$ of total imports in 2011 and its price has risen by $21 \%$ per year since 1994 (see figure 2). The resulting trade deficit has been offset by remittances from abroad and FDI, which have contributed to the narrowing balance- 
FIGURE 2

Nicaragua: implicit price index for key export and import commodities, 1994-2011 $(1994=100)$

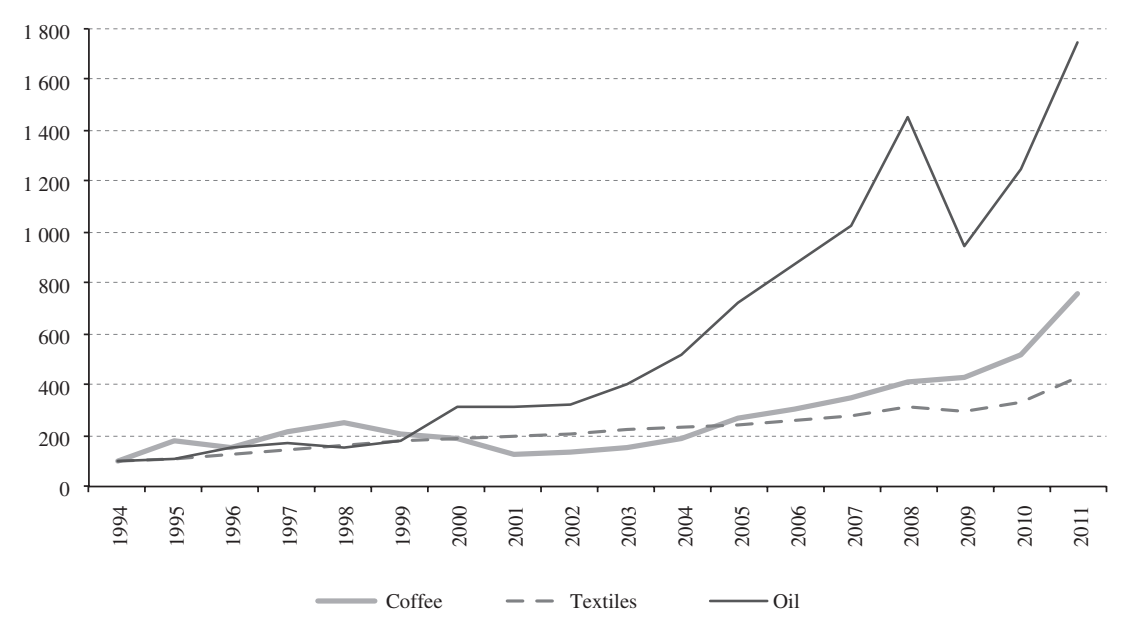

Source: Central Bank of Nicaragua.

of-payments current account deficit (see table 3). FDI has risen sharply since the second half of the 1990s, levelling off at around 5\% of GDP per year in the 2000s and subsequently climbing to almost $8 \%$ of GDP in 2010-2012 (see table 3). In the period 1990-2012, FDI inflows to Nicaragua fell 10 times, and by a substantial drop of over 1 percentage point of GDP on five of those occasions (see figure 3 ). Remittances inflows have been relatively steadier than FDI, although they also fell seven times between 1990 and 2012, most notably by 1.4 percentage points of GDP in 2006 and by 0.5 percentage points of GDP in 2009. The balance of payments, which is critical to achieving sustained economic growth, is highly vulnerable to weaker inflows of remittances and FDI. Those external vulnerabilities could jeopardize the country's efforts to pursue human development goals.

FIGURE 3

Nicaragua: net foreign direct investment and remittances inflows, 1990-2012 (Percentages of GDP)

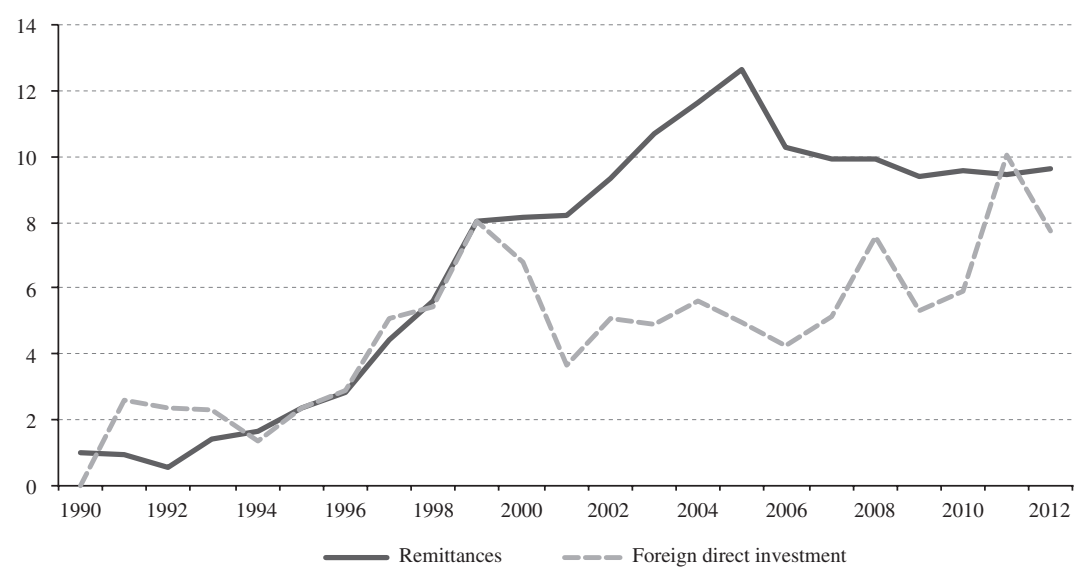

Source: Central Bank of Nicaragua.

GDP: gross domestic product. 


\section{III}

\section{Modelling framework}

An economy-wide modelling framework is needed for the scenario analysis conducted to quantify the additional public social spending and financing required to meet the Millennium Development Goal targets. The Maquette for MDG Simulations (MAMS) is used in this paper. This dynamic-recursive CGE model is a system of simultaneous, non-linear equations whereby an equilibrium is achieved using equations that define behaviour (for consumers, producers, and so on), macroeconomic balance (fiscal accounts, balance of payments, savings-investment balances, and so on) and market equilibrium (for goods and services, factors, and so on), among other elements. MAMS is described in detail in Lofgren and Díaz-Bonilla (2010) and Lofgren, Cicowiez and Díaz-Bonilla (2013). As these documents explain, the model is innovative in its inclusion of a set of basic human development objectives in its module on the Millennium Development Goals and education, on which more detail is provided below. This paper goes further by applying MAMs to address the external vulnerabilities of Millennium Development Goal achievement in Nicaragua.

The use of a dynamic-recursive CGE model such as MAMS is justified because the strategies implemented in pursuit of development goals are likely to have a major impact throughout the economy. Such strategies can affect demand and supply in the different markets (goods and services, factors and foreign exchange), and the related adjustments may call for significant trade-offs throughout the period for achieving the development goals and beyond. MAMS specifically takes into consideration the possible synergies between the different Goals in its module on the Millennium Development Goals and education. Such synergies may influence the required expansion of services (for example, greater safe water supply coverage may reduce the need for health service expansion) or the speed at which the various Goals are achieved.

The strategy adopted to finance the public spending required to achieve these development goals also affects the outcomes. For example, foreign financing could have an impact on the real exchange rate, while financing through domestic tax revenues could reduce private consumption demand and domestic borrowing could crowd out credit resources for private investment. Without doubt, increased public spending is essential for meeting human development goals, but adjustments in the real exchange rate, real wages and other relative prices could raise the unit costs for meeting these goals -along with the costs for other sectors- or discourage exports, thereby widening the external deficit that needs to be financed, among other consequences. Productivity gains accruing exclusively from reaching higher human development standards will take some time to materialize and are thus unlikely to trigger an immediate impact on economic growth. MAMs is a useful tool for assessing the macroeconomic trade-offs of financing development through public spending in order to establish whether the potential economic and social gains to be reaped in the long run would offset these trade-offs.

The module on the Millennium Development Goals and education specifies the main determinants of achieving the Goals that are not directly associated with income poverty (that is, the non-poverty Goals) and the direct impact of enhanced public spending on infrastructure and services related to the Millennium Development Goals (see table 4). It considers specific targets for achieving the non-poverty Goals of universal primary education (Goal 2), reducing under-five and maternal mortality (Goals 4 and 5) and increasing access to safe water and basic sanitation (Goal 7). The indicator used for Goal 2 is not enrolment but the net on-time primary completion rate, which is a function of student behaviour (enrolment, promotion, graduation), since most developing countries have already achieved acceptable levels of enrolment in primary education. A target is set for the timely completion, without repetition and for the relevant age cohort, of primary school. Student behaviour, in turn, depends on the quality of education (service delivery per student), household consumption per capita (as an indicator of living standards), income incentives (the expected wage premium from education), child mortality (a proxy for the health status of the student population) and public infrastructure (such as roads, bridges, electricity networks, and so on, which facilitate access to and the functioning of education centres). As the completion rate in all education cycles rises, the skill composition of the labour force shifts towards a larger share of skilled workers, leading to a direct association between the functioning of the education system and the labour market. Under-five and maternal mortality 
rates, on the other hand, are determined by the per capita availability of public and private health services, household consumption per capita, the level of public infrastructure (such as roads, bridges, electricity networks, and so on, which facilitate access to and the functioning of health centres and hospitals), and the coverage of water and sanitation services. The determinants of access to water and sanitation are household consumption per capita, the provision of water and sanitation services by public or private providers and public infrastructure.

The effectiveness of the determinants of the nonpoverty Goals follows a non-linear pattern. Logistic functions for the "production" of the different Millennium Development Goal indicators and student behaviours are generated in such a way that each determinant becomes relatively less effective as progress is made towards the target. This non-linearity feature makes MAMs a more appropriate tool to establish whether a country is ontrack towards its development goals than other models that have tried to establish this by projecting past trends forward in a linear fashion. Although social services can be provided publicly or privately, only new government investment and current spending will lead to the kind of policy-driven increase in the supply of social services and public infrastructure that can secure the attainment of one or more development targets. Scenarios are simulated in which the government mobilizes sufficient domestic or foreign resources to finance the new spending required to meet the targets. The mathematical statement of the model that captures these transmission mechanisms is explained in detail in Lofgren and Díaz-Bonilla (2010) and Lofgren, Cicowiez and Díaz-Bonilla (2013).
The goal of reducing extreme poverty (Millennium Development Goal 1) is not targeted in the same way as the non-poverty Goals because of the absence of tools that policymakers could realistically use to achieve specific poverty outcomes in most real-world, developing-country contexts. Owing to the use of representative households, CGE models such as MAMS typically fail to give the level of income distribution detail that is required to properly estimate poverty at the household level. This shortcoming is overcome by using the non-parametric microsimulation model described and applied in Vos and Sánchez (2010).

Thus, income distribution as recorded in household surveys is taken into account, without making assumptions about the income distribution within the CGE model representative household. For a number of labour market variables taken from the CGE model scenarios (unemployment by occupation type, employment and wages by sector, overall average remuneration level and skill composition of the employed population), changes for each year of the scenarios are calculated relative to a base year for the microsimulations. These changes are approximated in the microsimulations using a random selection procedure within labour market segments narrowly defined according to occupational categories by educational level and sectors of employment. A random selection process is applied to determine, for each year, which working-age persons change their labour force status (employment versus unemployment); which change their sector of employment; which employed persons upgrade their level of education; and how new labour incomes are assigned to individuals in the sample. The

TABLE 4

\section{Determinants of the non-poverty Millennium Development Goals}

\begin{tabular}{|c|c|c|c|c|c|}
\hline Millennium Development Goal & Service delivery & $\begin{array}{l}\text { Household consumption } \\
\text { per capita }\end{array}$ & $\begin{array}{c}\text { Wage } \\
\text { incentives }\end{array}$ & $\begin{array}{c}\text { Public } \\
\text { infrastructure }\end{array}$ & $\begin{array}{l}\text { Other Millennium } \\
\text { Development Goals }\end{array}$ \\
\hline \multicolumn{6}{|l|}{ 2: Primary education } \\
\hline (i) Enrolment & 1.0000 & 0.3063 & 1.3650 & 0.3815 & -0.6300 (MDG 4) \\
\hline (ii) Promotion & 1.0000 & 0.1187 & 1.5167 & 0.1715 & -0.0035 (MDG 4) \\
\hline 4: Under-five mortality & -0.8550 & -0.6133 & & -0.2000 & $\begin{array}{l}-0.3268(\text { MDG } 7 \mathrm{w}) \\
-0.3268(\text { MDG 7s) }\end{array}$ \\
\hline 5: Maternal mortality & -0.9500 & -0.6133 & & -0.2000 & $\begin{array}{l}-0.1315(\text { MDG 7w) } \\
-0.1315(\text { MDG 7s) }\end{array}$ \\
\hline 7: Access to safe water & 0.3600 & 0.1120 & & 0.0020 & \\
\hline 7: Access to basic sanitation & 0.8000 & 0.6625 & & 0.5880 & \\
\hline
\end{tabular}

Source: H. Lofgren, M. Cicowiez and C. Díaz-Bonilla, "MAMs-A computable general equilibrium model for developing country strategy analysis", Handbook of Computable General Equilibrium Modelling, P.B. Dixon and D.W. Jorgenson (eds.), vol. 1A, Amsterdam, NorthHolland, 2013, p. 223; and estimates of underlying elasticities for Nicaragua (presented in brackets) based on the analysis documented in J. Pacheco, "Determinantes socioeconómicos de la educación, la mortalidad y el acceso al agua potable y el saneamiento en Nicaragua: Un análisis econométrico", 2013 [online] http://www.un.org/en/development/desa/policy/capacity/country_documents/nicaragua_determinantes.pdf.

Note: MDG 7w refers to the Millennium Development Goal target on access to drinking water and MDG 7s refers to the target on sanitation. 
key assumption is that, on average, these occupational shifts caused by the random changes correctly reflect the impact of actual changes on the labour market. Because of the introduction of a process of random assignation, the microsimulations are repeated many times for each year of the simulation period, in Monte Carlo fashion. Each time, the changes in the labour market are imposed on a given distribution derived from a recent household survey in order to generate a new labour income distribution. In order to run the microsimulations, the household survey year and the year with respect to which all occupational shifts taken from the CGE model are expressed are consistent. Changes in non-labour incomes, such as government transfers and remittances from abroad, are also computed for each year of the scenarios relative to the base year for the microsimulations, using values taken from the CGE model. These changes are proportionally scaled up or down to re-estimate the new household income distribution. That figure and the marginal propensity to consume by product are in turn used to generate a new consumption distribution. On the basis of this process, $95 \%$ confidence intervals are constructed for the poverty and inequality indices estimated using the newly generated income and consumption distributions.

\section{IV}

\section{Data, calibration and baseline scenario}

The basic accounting structure of MAMS is derived from a Social Accounting Matrix (SAM) for 2006. It integrates data from official national accounts (supply and use tables, institutions' accounts and key macroeconomic aggregates), fiscal accounts, balance-of-payments information and a recent household survey into a consistent accounting framework. This matrix possesses the following key characteristics: (i) a fairly detailed treatment of public investment and its financing; (ii) the inclusion of seven areas of government service provision in primary education, secondary education, tertiary education, health, water and sanitation, public infrastructure and other government services; (iii) coverage of privatesector services, including primary education, secondary education, tertiary education, health and other private services; (iv) the disaggregation of other economic activities into various sectors, with separate accounting for those sectors most typically affected by external shocks (such as coffee, textiles and oil); (v) the division of labour as a factor of production into three categories that are each linked directly to an educational cycle, namely, workers who have not completed secondary education (unskilled), workers who have completed secondary but not tertiary education (skilled) and workers who have completed tertiary education (highly skilled), ${ }^{4}$ and

\footnotetext{
4 Other factors of production include public capital stocks by government activity, private capital stock, and natural resources used in mining and agriculture.
}

(vi) the inclusion of the government, a representative household (the domestic non-government sector) and the rest of the world as institutional agents.

In addition to the SAM, the MAMS dataset also includes data relating to the Millennium Development Goals (as recorded in table 1 for the non-poverty indicators), the labour market and a set of elasticities. Other key pieces of information used to calibrate the model are: (i) a possible scenario where the targets would be met on the basis of the past evolution of the determinants listed in table 4; (ii) the number of students at the different stages of the educational cycle; (iii) student behaviour patterns in terms of promotion rates and other indicators, and (iv) the number of workers and initial unemployment rates for the three categories of workers. All of these data are from official sources: the Central Bank of Nicaragua, the Ministry of Finance and Public Credit, the Ministry of Education and the National Institute of Information for Development. The elasticities define behaviour in production, trade, consumption and Millennium Development Goal functions (see table 4). Logistic models have been estimated econometrically to identify the influence of both supply and demand factors on outcomes in education, health, and access to safe water and sanitation. The findings of these empirical analyses are presented in Pacheco (2013) and have been used to define a set of elasticity values to calibrate the Millennium Development Goal functions. According to these values, the wage incentive appears to be the main 
determinant of enrolment and promotion in Nicaragua's primary education system, whereas per capita service delivery in health, water and sanitation - for which per capita public spending is the policy variable in MAMSdetermines most changes in mortality rates and access to safe water and basic sanitation. All other elasticities have been defined on the basis of estimates carried out to calibrate similar CGE models for Nicaragua used and documented in Sánchez and Vos (2006 and 2010) and Gámez and others (2011). ${ }^{5}$

A baseline scenario was generated after completing the model calibration process, constituting a benchmark against which the different alternative scenarios could be compared. Starting from a base year (2006), the baseline scenario replicates actual economic performance under policies implemented in recent years (until around 2012) and projects these figures up to 2020. Economic growth assumptions include the deceleration in GDP growth caused by the global financial crisis of 2008-2009. GDP grew at an annual rate of 3.1\% during the period 2007-2012 and is projected to continue growing by about $4.5 \%$ per year from 2013 to 2020 , according to the Central Bank of Nicaragua. In order to mimic public expenditure policies of the recent past, government consumption and other components of recurrent spending follow a closure rule: that is to say, they represent a pre-defined share of GDP (3.3\% for education, $2.3 \%$ for health and $0.5 \%$ for water and sanitation). Government investment spending depends on the demand for capital in the public services sector and that demand, in turn, varies as the government consumes to deliver services. According to another closure rule, any emerging fiscal deficit (or surplus) is assumed to be financed (adjusted) by (modest) transfers from the rest of the world, which consist essentially in grant aid. Official projections of foreign and domestic debt stocks are used, including programmed debt repayments and relief, and tax revenues are expected to continue growing slowly until they reach $18.5 \%$ of GDP in 2020. Private investment is assumed to remain fixed as a share of GDP, while savings rates of private agents adjust endogenously to ensure that the consistency requirement of the model is met and that total savings equal total investment. Observed progress towards the Goals until around 2011 is also reproduced through the calibration, using the elasticity values presented in table 4 , and is further projected into the future under

5 The database of the model is not annexed to this paper because of its size; however, it is available upon request from the author. the aforementioned continuation of economic trends and public spending and revenue policies. ${ }^{6}$

The microsimulation model was applied using data from the Living Standards Measurement Study (LSMS) survey conducted by the National Institute of Information for Development in 2009. Thus, occupational shifts and changes in transfers with respect to 2009 were estimated for every year of the period 2010-2020, using the LSMS 2009 data to run the microsimulations for the baseline scenario and for all the other hypothetical alternative scenarios. Transfers include transfers to households associated with education, food stamps, grants from institutions and donations by friends or relatives (a proxy of remittances given that most of these donated funds come from abroad and remittances are not specifically identified as a variable in the survey).

The baseline scenario depicts the evolution of the Millennium Development Goal indicators under the continuation of economic conditions and public spending and revenue policies, taking into consideration the complementarities or synergies between the various Goals. As described above, MAMs takes into account the extent to which improved health helps to accelerate progress towards the education goal and to which increased access to safe water and basic sanitation contributes to reducing mortality rates. Continued public spending on services related to the Goals (primary education, health care and water and sanitation) is one of the key drivers of outcomes under the baseline scenario. As a result, primarily, of this driver, and also of all the other determinants listed in table 4 (including per capita consumption, which is propelled by steady economic growth), progress is made towards the Millennium Development Goals under the baseline scenario, but not all of them are met by 2015 (see figure 4). Under the baseline scenario, the target $87 \%$ completion rate at the expected age for boys and girls enrolled in primary school is not achieved even by 2020. The basic sanitation target is met in 2019. The outlook is more encouraging for the maternal mortality goal which is within reach by 2016 , on the back of steady growth in public and private spending, as well as improved coverage of drinking water and sanitation services. As will be shown below, poverty decreases under the baseline scenario, but not enough to meet the international target for extreme poverty.

\footnotetext{
${ }^{6}$ With regard to the rules used to clear factor markets, rents adjust to clear the market of the capital factor. Land and natural resources grow at an exogenous rate and are activity-specific. The labour market clears through unemployment; provided that the unemployment rate does not decline to a minimum or natural unemployment rate, at which point the labour market clears through wages.
} 
A. Goals 2 and 7

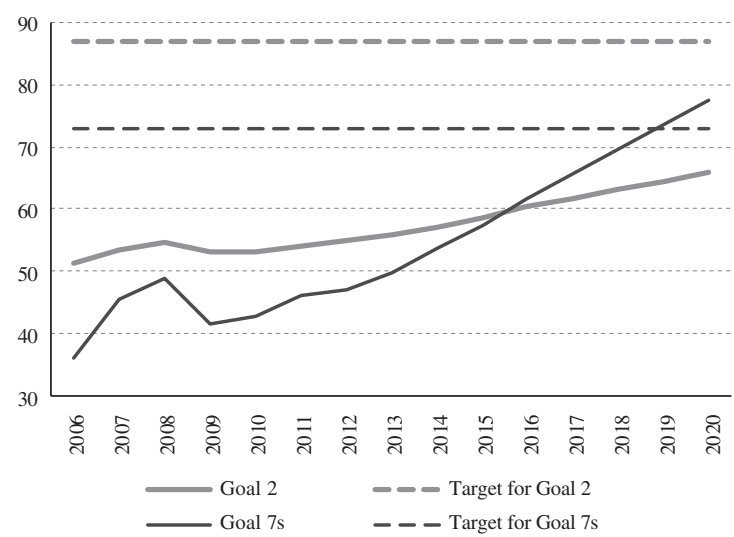

B. Goals 4 and 5

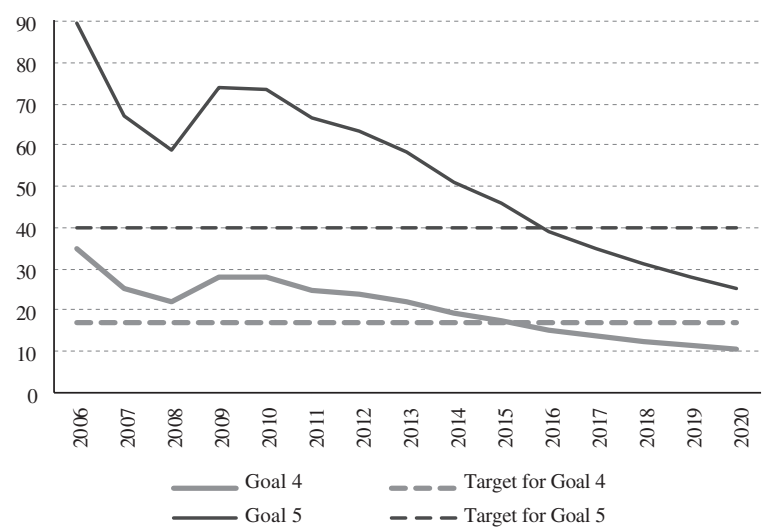

Source: prepared by the author on the basis of the Maquette for MDG Simulations (MAMS) for Nicaragua.

Note: indicators and targets are consistent with those presented in table 2, except for those for Goal 2, which here refers to the net on-time primary completion rate. The $87 \%$ target for the Goal 2 indicator is derived from the $98 \%$ target for entry and promotion rates in primary education. Goal 7s refers to the Millennium Development Goal target on access to improved sanitation.

\section{$\mathrm{V}$}

\section{Analysis of hypothetical scenarios}

Two sets of hypothetical scenarios are analysed by comparing their results against the baseline scenario. The first set comprises four financing scenarios that trace a path towards fully meeting the three non-poverty targets that are not met by 2015 under the baseline scenario, as shown in figure 4 . The variable that is adjusted in these scenarios is public spending, which includes all investment and current spending needed to deliver public primary education and, to a lesser extent, sanitation services. This Goal-related public spending is scaled up starting in 2014 until all non-poverty targets under consideration are met by either 2015 or 2020 , using either foreign resources or direct tax revenues as alternative sources of financing. Health spending does not increase because, by meeting the sanitation target and continuing to expand the coverage of the drinking water supply in these scenarios, mortality rates fall to the extent needed to meet the respective targets. As indicated above, the distance between mortality rates in 2015 and the targets is small under the baseline scenario (see figure 4). In the second set of hypothetical scenarios, the financing scenario - under which the non-poverty targets are met by 2020 using foreign resources to finance public social spending - is combined with one of the following five external shocks: ${ }^{7}$

- pcoffdec: $20 \%$ drop in the world price of coffee.

- ptextdec: $20 \%$ drop in the world price of textiles.

- poilinc: $20 \%$ increase in the world price of refined oil.

- fdidec: reduction of 2 percentage points of GDP in FDI inflows.

- remdec: reduction of 2 percentage points of GDP in remittances inflows.

All five external shocks are imposed for the 2014-2020 period, relative to the baseline scenario. ${ }^{8}$ A deliberate decision was taken to simulate relatively

\footnotetext{
7 The findings regarding the effects of external shocks on human development are almost the same under an alternative scenario where tax revenue is the source of financing for public spending. The results for the tax financing scenario in combination with external shocks are therefore not presented, although they are available upon request. 8 Note that all the alternative scenarios start from 2006, but diverge from the baseline only from 2014.
} 
modest external shocks in order to better understand the high degree of external vulnerability of Nicaragua's economic and human development. As will be shown below, the targets would not be met as fast or at all, in some instances, under the scenarios with external shocks.

\section{Financing human development and macroeconomic trade-offs}

The evidence under the baseline scenario shows that the time span to 2015 is too short for Nicaragua to achieve the Millennium Development Goals, most notably the target relating to primary school completion, but also the targets on increased access to basic sanitation services and reduced maternal mortality (see figure 4). The findings for the first set of alternative scenarios further suggests that these goals are not within reach by 2015 because considerable amounts of additional public spending would have to be front-loaded and then maintained beyond 2015 to avoid setbacks in human development. ${ }^{9}$ Public spending on primary education would have to rise by approximately 6 percentage points of GDP - nearly $67 \%$ would be allocated to government consumption - in order for the primary completion rate to be on track by 2015 (see table 5). An additional

${ }^{9}$ In fact, in the scenario in which the non-poverty targets are met by 2015, the share of Goal-related public spending as a percentage of GDP in 2015 is maintained constant in 2016-2020, such that Millennium Development Goal indicators continue to improve as a result of steady GDP growth. percentage point of GDP or slightly more is required to enhance basic sanitation services, especially through investment in sanitation infrastructure, in order to meet the relevant target and, in turn, clear the way for the achievement of the maternal mortality goal by 2015 . The additional public spending required to meet all the non-poverty targets together represents just over $7 \%$ of GDP, which is well above the Goal-related spending of $4.8 \%$ of GDP recorded in the baseline. ${ }^{10}$

Financing such large amounts of public spending would be unrealistic in the remaining time span to the end of 2015. Foreign public debt would rise by 23 percentage points of GDP in 2015 and by 44 percentage points of GDP in 2020, respectively, relative to the baseline, under a scenario in which additional Goal-related public spending was fully financed using foreign borrowing rather than aid (see figure 5.A). ${ }^{11}$ The alternative analysed here is to finance the additional public spending required to achieve

\footnotetext{
${ }^{10}$ Sánchez and Vos (2009 and 2010) estimated that the additional public spending required to meet the Millennium Development Goal targets in Nicaragua by 2015 was equivalent to $6.4 \%$ of GDP. The figure in this paper is somewhat higher because the simulation period to 2015 is shorter - in other words, the base year is more recent- and the baseline scenario takes more accurate account of the adverse effects of the global financial crisis on the Millennium Development Goals because it uses more recent data.

${ }^{11}$ Foreign financing is needed beyond 2015 in order to ensure that the share of Goal-related public spending as a percentage of GDP in 2015 remains constant in 2016-2020. Under the baseline scenario, foreign public debt drops sharply, in line with the trend observed in past years and with official projections of foreign debt stocks that take into account programmed debt repayments and relief.
}

(Percentages of GDP)

\begin{tabular}{|c|c|c|c|c|c|c|}
\hline & \multicolumn{2}{|c|}{$\begin{array}{l}\text { Spending under the } \\
\text { baseline scenario }\end{array}$} & \multicolumn{4}{|c|}{$\begin{array}{l}\text { Additional spending required per year in } 2014-2020 \\
\text { under the financing scenarios that seek to meet the targets by: }\end{array}$} \\
\hline & 2006-2013 & 2014-2020 & $\begin{array}{l}2015 \text {, with } \\
\text { foreign borrowing }\end{array}$ & $\begin{array}{l}\text { 2015, with } \\
\text { direct taxation }\end{array}$ & $\begin{array}{l}2020 \text {, with } \\
\text { foreign borrowing }\end{array}$ & $\begin{array}{l}\text { 2020, with } \\
\text { direct taxation }\end{array}$ \\
\hline Education & 1.63 & 1.67 & 6.04 & 6.10 & 3.71 & 4.29 \\
\hline Consumption & 1.49 & 1.47 & 4.05 & 4.05 & 2.56 & 2.92 \\
\hline Investment & 0.14 & 0.20 & 1.99 & 2.05 & 1.14 & 1.36 \\
\hline Health & 2.33 & 2.50 & 0.00 & 0.00 & 0.00 & 0.00 \\
\hline Consumption & 2.08 & 2.17 & 0.00 & 0.00 & 0.00 & 0.00 \\
\hline Investment & 0.25 & 0.33 & 0.00 & 0.00 & 0.00 & 0.00 \\
\hline Water and sanitation & 0.51 & 0.66 & 1.22 & 1.14 & 0.00 & 0.00 \\
\hline Consumption & 0.01 & 0.01 & 0.34 & 0.34 & 0.00 & 0.00 \\
\hline Investment & 0.51 & 0.65 & 0.88 & 0.80 & 0.00 & 0.00 \\
\hline Total & 4.48 & 4.83 & 7.26 & 7.24 & 3.71 & 4.29 \\
\hline
\end{tabular}

Source: prepared by the author on the basis of the Maquette for MDG Simulations (MAMs) for Nicaragua. GDP: gross domestic product. 
the non-poverty goals by raising additional direct tax revenues by 12 percentage points of GDP in 2015 and by 5 percentage points of GDP in 2020, respectively, with respect to the baseline (see figure 5.B). This financing strategy would also be unfeasible considering that the government has already made concerted efforts to raise taxes.

Nicaraguan policymakers would find it more realistic to pursue a Millennium Development Goal strategy with a relatively longer time frame whereby the frontloading of public spending and financing would be less demanding and would not jeopardize the fiscal stance. The alternative scenarios show that the government would save 3 percentage points of GDP or more in public spending by aiming to achieve the non-poverty Millennium Development Goals by 2020 instead of by 2015 (see table 5). The additional public spending required to ensure that the goal on primary completion is within reach by 2020 would subsequently spur economic growth under a less binding fiscal constraint, which would in turn stimulate employment and help reduce the incidence of poverty. The resulting increase in income per capita would boost private demand for education, health care, water and sanitation and thus have a positive impact on progress towards the Millennium Development Goals.
Under the foreign borrowing scenario, access to basic sanitation would be on course for 2020, whereas the targets for under-five mortality and maternal mortality would be met in 2015 and 2016, respectively.

The additional public spending required to meet all the non-poverty targets by 2020 is 0.6 percentage points of GDP lower if foreign borrowing is the source of the financing rather than taxation (see table 5). Direct taxation reduces private disposable income and thus depresses private demand for social services, such as education, and constrains the private savings available for investment (see table 6). Under the direct taxation scenario, the government would be required to step up spending to a greater extent - than under the foreign financing scenario - in order to offset the reduction in private spending and meet the targets. New public spending injected into non-tradable sectors of the economy would exert pressure on the real exchange rate, leading to a degree of appreciation that would drag down export growth and push up import growth compared with the baseline scenario. The effect of the real exchange rate appreciation would be exacerbated if inflows of foreign resources were mobilized to finance additional public spending needs. Moreover, under a foreign borrowing scenario, relatively less financing would be needed to

\section{Nicaragua: foreign public debt and tax revenues under the baseline and Millennium Development Goal financing scenarios, 2006, 2015 and 2020 (Percentages of GDP)}
A. Foreign public debt under the foreign borrowing scenario

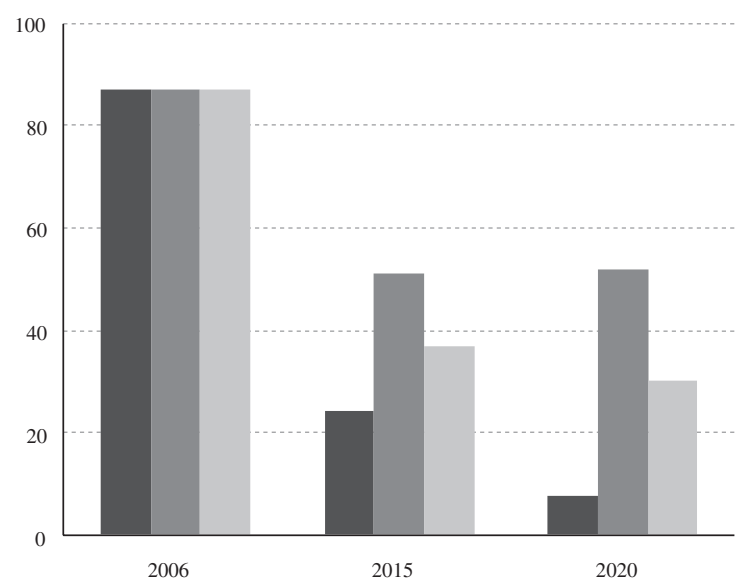

B. Tax revenues under the tax financing scenario

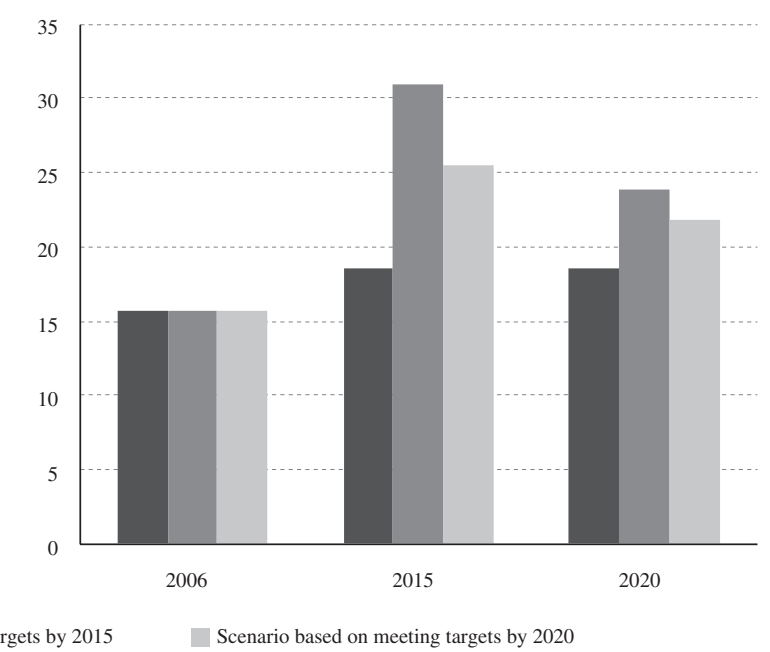

Source: prepared by the author on the basis of the Maquette for MDG Simulations (MAMS) for Nicaragua. GDP: gross domestic product. 
cover the additional public spending if the targets were met by 2020: foreign public debt would represent $30 \%$ of GDP in 2020 if the targets were met by that year, 20 percentage points less than under the corresponding scenario in which targets are met by 2015 (see figure 5).

The financing strategy chosen matters for GDP growth. In the foreign financing scenarios GDP growth was slightly higher than in the baseline scenario, whereas the use of direct taxation in the alternative financing scenarios would hurt economic growth by crowding out private spending compared with all the other scenarios (see table 6). ${ }^{12}$ For the short to medium run, Nicaragua can continue to rely on foreign sources to complement domestic resources for financing spending towards the achievement of human development goals. However, reducing the dependence on aid and concessional loans will call for more fiscal reforms to gradually replace foreign financing with tax revenues. Furthermore, using foreign resources to finance development for a long period of time could undermine export competitiveness through the appreciation of the real exchange rate. This could, in turn, discourage exports, thereby widening the external deficit and leading to an undesirable structural change away from the most dynamic industries, thus hurting economic growth.

These simulated Millennium Development Goal financing strategies would also bear consequences for

12 Growth in GDP, and its spending components, is expected to be slightly higher when financing is mobilized to achieve the Millennium Development Goals by 2015 because the stimulus from front-loading Goal-related public spending is much larger. This is not true under the tax financing scenario because of the crowding-out effect on private spending. poverty and inequality. The incidence of poverty and extreme poverty at the national level fall dramatically under the baseline scenario by 8.7 percentage points and 4.2 percentage points, respectively, between 2009 and 2020 (see table 7). Of these reductions, 7.3 percentage points and 4 percentage points, respectively, are attributable to an overall increase in the population's well-being thanks to higher labour incomes, and the rest of the change is driven by transfers from the government and the rest of the world.

When additional public spending is stepped up and financed through resources from abroad to meet the nonpoverty Millennium Development Goal targets by 2020 , the demand push has a multiplier effect throughout the economy resulting in higher average wages and lower unemployment. These labour market effects produce net income gains that lead to further reductions in moderate and extreme poverty rates, thus achieving the international goal of reducing extreme poverty to $9.7 \%$ (see table 7). This outcome is not replicated under the tax financing scenario, however, where poverty rates are actually higher than under the baseline scenario as a result of the crowding-out effect on private spending, which offsets the demand push from public spending. Poverty rates do not decline to a greater extent in the financing scenarios because, in addition to the aforementioned adverse macroeconomic effects of financing public spending (crowding-out of private spending and reduced export competitiveness), wages are less equally distributed as public-sector demand for doctors, teachers and other highly qualified workers, who are in limited supply in Nicaragua, rises. The Gini coefficient of consumption per capita is larger in all of the Millennium Development Goal financing scenarios than in the baseline scenario.

Nicaragua: growth of real GDP and its spending components under the baseline and Millennium Development Goal financing scenarios, 2007-2020

(Percentages)

\begin{tabular}{|c|c|c|c|c|c|c|}
\hline & \multirow{2}{*}{$\begin{array}{c}2007-2013 \\
\text { under all } \\
\text { scenarios }\end{array}$} & \multirow{2}{*}{$\begin{array}{l}\text { 2014-2020 } \\
\text { under the } \\
\text { baseline } \\
\text { scenario }\end{array}$} & \multicolumn{4}{|c|}{ 2014-2020 under the financing scenarios that seek to meet the targets by: } \\
\hline & & & $\begin{array}{l}2015 \text {, with } \\
\text { foreign borrowing }\end{array}$ & $\begin{array}{c}\text { 2015, with } \\
\text { direct taxation }\end{array}$ & $\begin{array}{l}2020, \text { with } \\
\text { foreign borrowing }\end{array}$ & $\begin{array}{c}\text { 2020, with } \\
\text { direct taxation }\end{array}$ \\
\hline Private consumption & 2.13 & 3.58 & 4.15 & 3.21 & 3.89 & 3.22 \\
\hline Government consumption & 0.89 & 4.48 & 8.71 & 8.78 & 6.97 & 7.34 \\
\hline Private investment & 6.17 & 3.88 & 3.99 & 3.49 & 3.93 & 3.59 \\
\hline Government investment & 4.37 & 7.77 & 57.50 & 48.97 & 22.18 & 22.92 \\
\hline Exports & 6.36 & 5.46 & 5.15 & 4.74 & 4.68 & 4.95 \\
\hline Imports & 2.73 & 4.06 & 4.64 & 3.62 & 4.26 & 3.75 \\
\hline GDP & 3.24 & 4.42 & 4.59 & 4.34 & 4.51 & 4.37 \\
\hline
\end{tabular}

Source: prepared by the author on the basis of the Maquette for MDG Simulations (MAMs) for Nicaragua. 
Nicaragua: poverty indicators and Gini coefficient under the baseline and Millennium Development Goal financing scenarios using a 2020 deadline for the targets, 2009, 2015 and 2020

\begin{tabular}{|c|c|c|c|c|c|c|c|}
\hline & \multirow{2}{*}{2009} & \multicolumn{2}{|c|}{ Baseline } & \multicolumn{2}{|c|}{ Foreign financing } & \multicolumn{2}{|c|}{ Direct tax revenues } \\
\hline & & 2015 & 2020 & 2015 & 2020 & 2015 & 2020 \\
\hline National extreme poverty (percentages) & 14.6 & 12.9 & 10.4 & 12.0 & 9.5 & 13.5 & 10.7 \\
\hline Gini coefficient of consumption per capita & 0.4828 & 0.4798 & 0.4832 & 0.4876 & 0.4924 & 0.4802 & 0.4836 \\
\hline
\end{tabular}

Source: prepared by the author on the basis of the Maquette for MDG Simulations (MAMS) for Nicaragua.

\section{External vulnerability of human development}

The economic outlook of Nicaragua is poised to improve if new stimulus from public spending on pursuing the development goals is not offset by the macroeconomic trade-offs of financing development. Nevertheless, external vulnerabilities must also be considered. Nicaragua has witnessed reductions in key export prices, oil price hikes resulting in swelling oil import bills, and unfavourable downturns in inflows of FDI and remittances. These external shocks jeopardize balance-of-payments stability and undermine economic growth, which can cause setbacks in human development. The external shocks simulated as part of the foreign financing scenario —using a 2020 deadline for the targets - were relatively modest in magnitude, yet they had the potential to weaken GDP growth (see figure 6). For example, a reduction of 2 percentage points of GDP in FDI inflows saps private investment and exports to a point where GDP growth falls by almost a quarter of a percentage point. Dips in world prices of key export commodities, such as coffee, have also taken a toll on economic growth.

Irrespective of the different transmission mechanisms through which they damage the economy, the simulated external shocks, though modest in magnitude, could limit economic growth in Nicaragua. These shocks

FIGURE 6

Nicaragua: real GDP growth under the foreign financing scenario using a 2020 deadline for meeting the targets, with and without external shocks, 2014-2020 (Percentages)

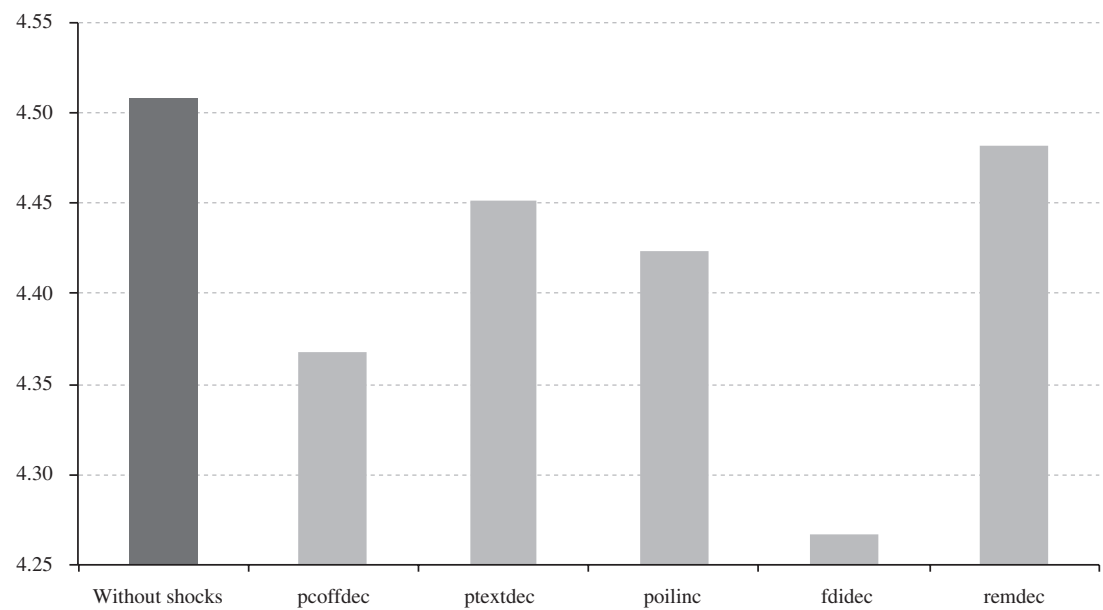

Source: prepared by the author on the basis of the Maquette for MDG Simulations (MAMS) for Nicaragua.

a pcoffdec: $20 \%$ drop in the world price of coffee; ptextdec: $20 \%$ drop in the world price of textiles; poilinc: $20 \%$ increase in the world price of refined oil; fdidec: reduction of 2 percentage points of GDP in foreign direct investment inflows; remdec: reduction of 2 percentage points of GDP in remittances inflows.

GDP: gross domestic product. 
would have an impact on the key determinants of Millennium Development Goal achievement, such as service delivery (using public and private spending in social sectors as a proxy) and per capita household consumption. In proportional terms, public social spending as a percentage of GDP is the same in the financing scenarios with and without external shocks. However, the slowdown in GDP growth resulting from the simulated external shocks implies lower public social spending in absolute terms than in the scenario without external shocks. External shocks also have an impact on the Millennium Development Goal indicators through a fall in private spending on social services and per capita consumption. As a consequence, progress towards the Millennium Development Goals is less encouraging by any measure. In the financing scenario with any of the external shocks, the target on net on-time primary completion rate would not be met (see figure 7). Furthermore, the reduction in per capita consumption mirrors the fall in household labour incomes owing to the economic growth slowdown triggered by the external shocks. Hence, extreme poverty would also rise, especially when the financing scenario is combined with the oil price shock. Though not shown in figure 7 for the sake of simplicity, the international target for extreme poverty is no longer met with any of the shocks and the attainment of the maternal mortality and sanitation targets is delayed when oil price and remittances shocks are simulated as part of the financing scenario. Relatively modest external shocks, therefore, have the potential to increase the public spending required to meet the Millennium Development Goals, hence making human development a more challenging aspiration for Nicaragua.

FIGURE 7
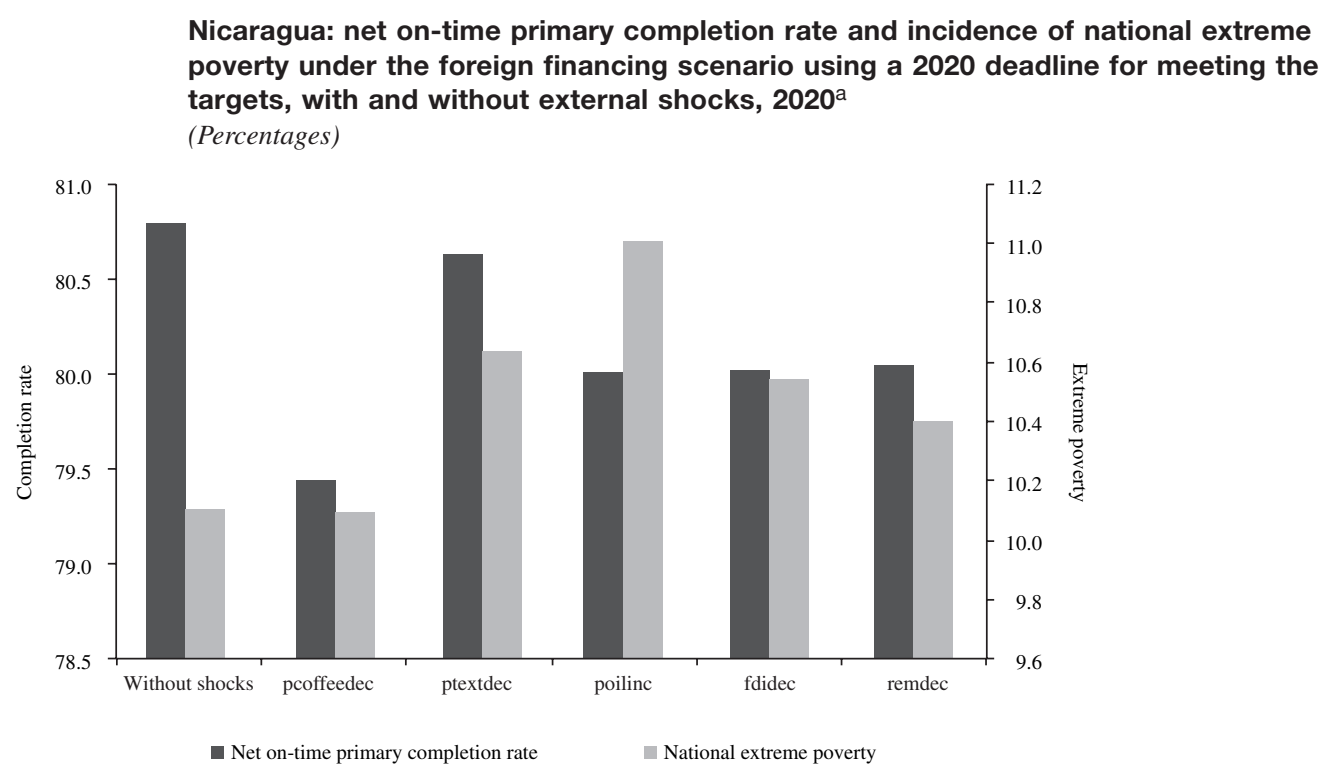

Source: prepared by the author on the basis of the Maquette for MDG Simulations (MAMS) and the microsimulation model for Nicaragua.

a pcoffdec: $20 \%$ drop in the world price of coffee; ptextdec: $20 \%$ drop in the world price of textiles; poilinc: $20 \%$ increase in the world price of refined oil; fdidec: reduction of 2 percentage points of GDP in foreign direct investment inflows; remdec: reduction of 2 percentage points of GDP in remittances inflows.

GDP: gross domestic product. 


\section{VI}

\section{Conclusions and policy implications}

Nicaragua is a small, open developing economy that has made notable economic and social progress in the past two decades, but still has high rates of extreme poverty and income inequality. Its economic growth typically fluctuates in response to external factors. The economy faces stubbornly pressing constraints with respect to generating resources domestically and by trading with the rest of the world, and relies heavily on foreign financing, including loans, grant aid and debt relief. In view of these resource mobilization constraints, Nicaragua faces challenges in its pursuit of development goals.

Progress towards the Millennium Development Goals has, by and large, been satisfactory. Extreme poverty and child and maternal mortality rates have fallen, and an ever larger share of the population has access to drinking water. But progress has been less encouraging with respect to achieving higher primary completion rates and coverage of basic sanitation services. This paper's scenario analysis corroborates the conclusions presented in Sánchez and Vos (2009 and 2010). That is to say, a continuation of existing economic trends and public spending and revenue policies is expected to translate into progress towards the Millennium Development Goals, including a marked trend towards poverty reduction, but not to the extent needed in order for Nicaragua to meet all the targets by 2015 . This paper extends the simulation period to 2020 in order to assess more realistic scenarios.

Nicaragua would need additional public social spending of about $7 \%$ of GDP per year to close the Millennium Development Goal gaps by 2015 and maintain all indicators on track thereafter, relative to the baseline scenario of continued GDP growth and no change in public spending policies. Approximately $87 \%$ of this new spending would have to be allocated to primary education. The macroeconomic repercussions of financing such large amounts of additional spending are sizeable. Economic growth would be undermined should the government opt to use high levels of additional direct tax revenues, since this would curtail private spending and demand for private social services. Alternatively, inflows of foreign resources would not crowd out private spending but, in the form of borrowing, would halt the decline in foreign debt and erode export competitiveness through real exchange rate appreciation. The same trade- off would be seen if those foreign resources came in the form of grant aid - although without debt accumulation. In view of these findings, achieving the Millennium Development Goals by 2015 is unfeasible for Nicaragua.

The time span to 2015 is simply too short for the government to take policy measures with a view to achieving all the Millennium Development Goals by the deadline. It would be more feasible if the country were to postpone the achievement of the most challenging goals. Not only would that make securing the required financing more achievable, but it would also multiply the effects of increased public spending more broadly throughout the economy, accelerating economic growth and helping buy time for the government to reduce reliance on foreign resources and reap the benefits of recent fiscal reforms. The alternative scenarios show that postponing the achievement of the Millennium Development Goals until 2020 would bring the additional public social spending required down to $3.7 \%$ or $4.3 \%$ of GDP, depending, respectively, on whether the source of the financing was from abroad or direct taxation. These scenarios offer a much more realistic public financing situation: for example, using foreign borrowing, the foreign debt stock would rise by 20 percentage points of GDP less to achieve the Goals by 2020 rather than by 2015 . In this case, the foreign debt trajectory would remain sustainable and closer to the relatively low, declining stock of the baseline scenario. The multiplier effect triggered by the government spending more gradually in social sectors over a longer period of time would contribute 1.3 percentage points of additional annual GDP growth relative to the baseline. These gains do not reflect the very long-term economic growth pay-offs that could be expected from investing in achieving the Millennium Development Goals. These pay-offs would be the result of factor accumulation and productivity growth from employing larger numbers of better educated and healthier workers over the years, as Sánchez and Cicowiez (2014) recently showed to be the case for four developing countries. Therefore, Nicaragua could realistically expect economic pay-offs from its past human development investments beyond 2020.

Nicaragua's policymakers will be unable to avoid relying on foreign borrowing to finance the investments needed to achieve the Millennium Development Goals. 
Foreign grant aid is no longer a viable option (unless its decline is systematically reverted by donors) and the country needs time to reap the benefits of recent fiscal reforms. Nonetheless, foreign sources of financing will have to be substituted gradually by new tax revenues if the government is to meet its commitment to lowering foreign debt levels.

All interventions aimed at enhancing resource mobilization will have to consider public spending requirements, not only to meet human development goals, but also to keep the country on track in the face of turbulent economic episodes caused by external shocks. This paper's scenario analysis shows that human development in Nicaragua is highly vulnerable to modest external shocks, whether these are caused by unfavourable world prices or reduced inflows of FDI or remittances. As shown in the scenario analysis, these shocks have the potential to halt the economic stimulus from public spending and drag down per capita income, leading to a number of human development and poverty setbacks, to the extent that many of the targets would no longer be attainable even by 2020 .

Reducing poverty and exposure to external vulnerabilities will require active policies that spur sustained economic and employment growth through the diversification of production and exports. Furthermore, economic growth should be made more inclusive by ensuring that productive transformation includes the integration of new technologies and activities that call for skilled labour and that teaching content is improved and the skills built by the education system are in high demand by the production sector. These changes could be triggered by the country's existing national development plans that are aimed at attracting FDI and implementing massive public infrastructure investment projects. In a broader sense, these conclusions and policy lessons apply to most small, open developing economies that are pursuing human development goals and could be a useful input for the United Nations post-2015 sustainable development agenda.

\section{Bibliography}

ECLAC (Economic Commission for Latin America and the Caribbean) (2013), Social Panorama of Latin America 2012 (LC/G.2557-P), Santiago, Chile. United Nations publication, Sales No. E.13.II.G.6.

Gámez, O. and others (2011), "Nicaragua", Vulnerabilidad económica externa, protección social y pobreza en América Latina, M.V. Sánchez and P. Sauma (eds.), Quito, Latin American Faculty of Social Sciences (FLACSO)/Economic Commission for Latin America and the Caribbean (ECLAC)/United Nations Department of Economic and Social Affairs.

Guimarães, J. and N. Avendaño (2011), "The great experiment: testing the PRSP approach in Nicaragua, 2000-2007", European Journal of Development Research, vol. 23, No. 2, Palgrave Macmillan.

Lofgren, H. and C. Díaz-Bonilla (2010), "MAMs: an economy-wide model for analysis of MDG country strategies - an application to Latin America and the Caribbean", Public Policies for Human Development. Feasible Financing Strategies for Achieving MDGs in Latin America and the Caribbean, M.V. Sánchez and others (eds.), London, Palgrave Macmillan.

Lofgren, H., M. Cicowiez and C. Díaz-Bonilla (2013), "MAMs-A computable general equilibrium model for developing country strategy analysis", Handbook of Computable General Equilibrium Modelling, P.B. Dixon and D.W. Jorgenson (eds.), vol. 1A, Amsterdam, North-Holland.

Pacheco, J. (2013), "Determinantes socioeconómicos de la educación, la mortalidad y el acceso al agua potable y el saneamiento en Nicaragua: Un análisis econométrico" [online] http:// www.un.org/en/development/desa/policy/capacity/country_ documents/nicaragua_determinantes.pdf.

Sánchez, M.V. (2011), "Welfare effects of rising oil prices in oilimporting developing countries", The Developing Economies, vol. 49, No. 3, Institute of Developing Economies.

Sánchez, M.V. and M. Cicowiez (2014), "Trade-offs and payoffs of investing in human development", World Development, vol. 62, Amsterdam, Elsevier.

Sánchez, M.V. and R. Vos (2010), "Nicaragua", Public Policies for Human Development. Feasible Financing Strategies for Achieving MDGs in Latin America and the Caribbean, M.V. Sánchez and others (eds.), London, Palgrave Macmillan.

(2009), "Impact of the global crisis on the achievement of the MDGs in Latin America", DESA Working Paper, No. 74, New York, United Nations Department of Economic and Social Affairs [online] http://www.un.org/esa/desa/papers/ 2009/wp74_2009.pdf.

(2006), "DR-CAFTA: ¿Panacea o fatalidad para el desarrollo económico y social en Nicaragua?", Estudios y Perspectivas series, No. 57 (LC/MEX/L.752), Mexico City, ECLAC subregional headquarters in Mexico [online] http://www. eclac.cl/ publicaciones/xml/0/27210/L752.pdf.

Vos, R. and M.V. Sánchez (2010), "A non-parametric microsimulation approach to assess changes in inequality and poverty", International Journal of Microsimulation, vol. 3, No. 1 [online] http://microsimulation.org/IJM/V3_1/IJM_25.pdf. 